Proceedings of the 10th International Ruminant Reproduction Symposium (IRRS 2018); Foz do Iguaçu, PR, Brazil, September 16 th to 20 th, 2018.

\title{
Neuroendocrine signaling pathways and the nutritional control of puberty in heifers
}

\author{
Rodolfo C. Cardoso ${ }^{1, *}$, Bruna R.C. Alves ${ }^{2}$, Gary L. Williams ${ }^{1,3}$ \\ ${ }^{1}$ Texas A\&M University, College Station, TX, USA. \\ ${ }^{2}$ University of Nevada, Reno, NV,USA. \\ ${ }^{3}$ Texas A\&M AgriLife Research, Beeville, TX, USA.
}

\begin{abstract}
Puberty is a complex physiological process in females that requires maturation of the reproductive neuroendocrine system and subsequent initiation of highfrequency, episodic release of gonadotropin-releasing hormone $(\mathrm{GnRH})$ and luteinizing hormone $(\mathrm{LH})$. Genetics and nutrition are two major factors controlling the timing of puberty in heifers. While nutrient restriction during the juvenile period delays puberty, accelerated rates of body weight gain during this period have been shown to facilitate pubertal development by programming hypothalamic centers that underlie the pubertal process. Among the different metabolic factors, leptin plays a critical role in conveying nutritional information to the neuroendocrine axis and controlling pubertal progression. Because GnRH neurons are devoid of the leptin receptor, leptin's effects on GnRH neurons must be relayed via an afferent neuronal network. Two neuronal populations located in the arcuate nucleus (ARC) that express the orexigenic peptide neuropeptide $\mathrm{Y}$ (NPY), and the anorexigenic peptide alpha melanocyte-stimulating hormone $(\alpha \mathrm{MSH})$, are key components of afferent pathways that convey inhibitory (NPY) and excitatory ( $\alpha \mathrm{MSH})$ inputs to $\mathrm{GnRH}$ neurons. In addition, ARC neurons expressing kisspeptin, a potent stimulator of $\mathrm{GnRH}$ release, are also involved in the nutritional regulation of puberty. Our studies have demonstrated that increased planes of nutrition during juvenile development result in morphological and functional changes in hypothalamic pathways comprising NPY, proopiomelanocortin (POMC), and kisspeptin neurons. Changes included differential expression of NPY, POMC, and Kiss1 in the ARC, and plasticity in the axonal projections to $\mathrm{GnRH}$ and kisspeptin neurons. Additionally, increased rates of body weight gain also promoted changes in the pattern of DNA methylation, a key epigenetic mechanism for regulation of gene expression. Finally, our most recent findings suggest that maternal nutrition during gestation can also induce structural and functional changes in hypothalamic neurocircuitries that are likely to persist long after pubertal maturation and influence reproductive performance throughout adulthood in cattle.
\end{abstract}

Keywords: heifers, hypothalamus, leptin, nutrition, puberty.

\section{Introduction}

Pubertal maturation in female mammals is an intricate physiological process that involves physical and behavioral changes associated with activation of the hypothalamic-pituitary-ovarian axis and subsequent establishment of reproductive cyclicity (Sisk and Foster, 2004). Reproductive maturation is initiated primarily at the hypothalamic level by the acceleration of gonadotropin-releasing hormone $(\mathrm{GnRH})$ secretion from GnRH neurons. The increase in pulsatile release of $\mathrm{GnRH}$ and subsequent rise in luteinizing hormone (LH) pulse frequency support the final maturation of ovarian follicles and steroidogenesis that are required for first ovulation (Ryan and Foster, 1980). The process of pubertal development is largely controlled by genetic and environmental factors, among which nutrition plays a prominent role. Data in humans and animals unequivocally demonstrate that increased nutrient intake during peripubertal development facilitates reproductive maturation in females (Ryan and Foster, 1980; Amstalden et al., 2011).

The timing of pubertal development has important implications for livestock production. In beef heifers, lifetime productivity is heavily dependent upon their ability to reach reproductive competence, to conceive early during their first breeding season, and to calve the first time by approximately 24 months of age (Lesmeister et al., 1973). Moreover, the incidence of multiple estrous cycles before the first breeding positively influences yearling fertility (Short and Bellows, 1971). However, a significant proportion of beef heifers within existing U.S. production systems fail to reach the developmental end-points necessary to achieve these objectives (Hughes, 2013). This is particularly true for later-maturing breeds (e.g., Bos indicus-influenced) in which the skeletal size required to support a healthy and safe pregnancy is frequently attained well before the establishment of regular estrous cycles. Therefore, a better understanding of the neuroendocrine mechanisms controlling puberty can assist in the development of novel managerial strategies that exploit brain plasticity during critical windows of development and lead to strategies for successfully programming the onset of puberty around 12 to 14 months of age.

The objectives of this review are to present an overview of the neuroendocrine processes controlling puberty in heifers, discuss the effects of nutrition on these processes, and summarize recent research findings regarding the programming effects of nutrition during early development on hypothalamic pathways that control reproduction. While this review focuses primarily on pubertal development in heifers, supportive data from other species including sheep and rodents are also discussed. 


\section{Neuroendocrine control of reproductive maturation}

\section{Estradiol negative feedback on gonadotropin secretion}

The onset of puberty in the heifer is characterized by a marked increase in the frequency of LH pulses that first becomes apparent at approximately 50 days before first ovulation. This characteristic increase serves as the most accurate predictor of pubertal onset (Day et al., 1984) and is resultant of coincident increases in pulsatile secretion of $\mathrm{GnRH}$ (Cardoso et al., 2014a). As frequency of LH pulses increases, their amplitude declines. However, despite the absence of consistent changes in pulse frequency or amplitude prior to 50 days, a trend for mean circulating concentrations of $\mathrm{LH}$ to increase has been detected in the heifer as early as 4 months preceding puberty (Swanson et al., 1972; Schams et al., 1981; Day et al., 1984). The heightened frequency of LH pulses reflects maturational changes of hypothalamic centers responsible for the pulsatile mode of $\mathrm{GnRH}$ release (Sizonenko and Aubert, 1986). These changes are highlighted by a marked decline in negative feedback responsiveness to estradiol-17 $\beta$ and are similar to those observed in the ewe lamb (Foster and Ryan, 1979). Although the synthesis and secretion of gonadotropins appear to be largely gonadal steroid-independent during the early postnatal period, a gonad-dependent suppression of $\mathrm{GnRH} / \mathrm{LH}$ develops during the juvenile period and reflects an increase in responsiveness to estradiol negative feedback (Day et al., 1984, 1986; Foster and Ryan, 1979). Ovariectomy at this time, without estradiol replacement, results in establishment of high-frequency pulses of $\mathrm{GnRH} / \mathrm{LH}$, typical of those at puberty. Conversely, estradiol replacement prevents the castration-induced rise in $\mathrm{GnRH} / \mathrm{LH}$ by restoring the inhibitory tone characteristic of the prepubertal state. Estradiol-mediated inhibition persists until hypothalamic changes associated with maturation of the reproductive neuroendocrine axis occur, at which time the GnRH pulse generator escapes from estradiol negative feedback in sheep (Foster and Ryan, 1979). Importantly, GnRH neurons do not contain estrogen receptor-alpha (ESR1; Lehman et al., 1993). Therefore, modifications in responsiveness to estradiol negative feedback are not mediated directly by estradiol at the level of the GnRH neuron. Moreover, although both follicle-stimulating hormone (FSH) and $\mathrm{LH}$ are ultimately controlled by GnRH from the hypothalamus, the change in negative feedback responsiveness to estradiol does not appear to result in a measurable modification in secretion patterns of FSH preceding puberty in heifers (Schams et al., 1981) or ewe lambs (Foster et al., 1975). Thus, a limitation in availability of FSH is not a primary factor regulating the timing of puberty in ruminants. Once pulses of LH occur at an interval of every 40 to $50 \mathrm{~min}$, circulating concentrations of LH increase markedly and result in heightened stimulation of ovarian follicles, an increase in circulating concentrations of estradiol, and initiation of a LH surge that induces first ovulation or luteinization of a large follicle (Kinder et al., 1987). The estradiol-induced surge of LH occurs through a parallel positive feedback effect of estradiol at hypothalamic components that mediate a prolonged surge of $\mathrm{GnRH}$. However, the ability of estradiol to induce a surge release of LH becomes functional between 3 and 5 months of age in heifers (Staigmiller et al., 1979) and thus is operable well before puberty.

Neuronal processes underlying the change in negative feedback responsiveness to estradiol

The neuronal network in the hypothalamus has the inherent ability to produce a pulsatile pattern of GnRH release and depends upon synchronous firing of GnRH neurons (Funabashi et al., 2000). However, since GnRH neurons do not contain ESR1, the role of changing responsiveness to estradiol negative feedback in modulating the GnRH pulse generator as puberty approaches has not been clearly delineated. Nonetheless, studies in mice have clearly shown that ESR1 is the major estrogen receptor mediating estradiol negative feedback effects on GnRH secretion (Dorling et al., 2003). Moreover, based on work in rodents, neurons located in the arcuate nucleus (ARC) that contain ESR1 are essential for communicating estradiol negative feedback (Bronson, 1981). In this context, it has been proposed that kisspeptin neurons are responsible for mediating the synchronized firing of GnRH neurons (Navarro et al., 2009; Qiu et al., 2016), underlie the estradiol feedback regulation of GnRH secretion (Dubois et al., 2016), and thus greatly influence pubertal maturation (Mayer et al., 2010; Redmond et al., 2011a, b) in both rodents and ruminants. Kisspeptin, a member of the RF-amide related peptide (RFRP) superfamily, is controlled by the Kiss 1 gene and its receptor (KISS1R), and is expressed in a variety of tissues, including the hypothalamus. Moreover, KISS1R colocalizes with GnRH neurons and is responsible for regulating the release of $\mathrm{GnRH}$ (Mayer et al., 2010). Gene mutations resulting in loss of this signaling pathway result in the failure to attain puberty in primates (Terasawa et al., 2013). Additional variants of Kiss1-containing cells have been localized specifically within the ARC and are termed KNDy neurons. Kisspeptin cells localized to the ARC coexpress two other neuronal peptides, neurokinin B (NKB) and dynorphin. KNDy neurons express receptors for both NKB and dynorphin, but do not contain kisspeptin receptors. Thus, KNDy cells function as a signaling network, secreting kisspeptin in response to their own release of NKB which stimulates release of GnRH by its direct action on both cell bodies and nerve terminals of GnRH neurons (Navarro et al., 2009; Lehman et al., 2010). Dynorphin is then released which terminates KNDy neuron activity. It has been proposed that the repeating nature of this paradigm provides, for the first time, a plausible explanation of cellular activity that represents the physical source of the GnRH pulse generator (Lehman et al., 2010; Goodman et al., 2013). Deletion of ESR1 in all kisspeptin-expressing neurons in a rodent model advances the onset of puberty, supporting the idea that ESR1 has the inherent ability to 
suppress GnRH/LH secretion and pubertal onset by its actions on kisspeptin neurons (Cheong et al., 2015). The interrelationship between ESR1 and kisspeptin neurons provides a potential basis through which changes in negative feedback responsiveness to estradiol could regulate the timing of puberty in heifers and ewe lambs. However, the exact mechanism remains elusive. Day et al. (1987) observed a reduction in the overall number of estradiol receptors in the mediobasal hypothalamus in intact heifers approaching puberty, similar to findings reported during juvenile development in rats (Kato et al., 1974). In contrast, Bedenbaugh et al. (2018) reported that the peripubertal increase in LH pulsatility in ovariectomized, estradiol-treated ewe lambs was associated with enhanced ESR1 mRNA expression in kisspeptin neurons in the ARC. Moreover, the absence of estradiol in ovariectomized ewe lambs was associated with the greatest ESR1 mRNA abundance and percentage of kisspeptin neurons containing ESR1 protein in the ARC. Therefore, changes in the expression of ESR1, particularly in kisspeptin neurons in the ARC, fail to explain the pubertal escape from estradiol negative feedback in the ruminant model.

\section{Impact of nutrition on pubertal development}

\section{Nutritional acceleration of puberty}

The important effects of nutrition controlling the reproductive neuroendocrine system and pubertal progression in heifers have been well established. Previous experiments conducted by our group (Cardoso et al., 2014a, b; Allen et al., 2017) and others (Gasser et al., 2006a) have demonstrated that increasing nutrient intake during the juvenile period can markedly advance the timing of puberty in beef heifers. In studies performed by Gasser et al. (2006a), the majority of heifers weaned at approximately 3.5 months of age and fed high-concentrate diets to achieve accelerated rates of body weight gain exhibited puberty before 300 days of age (precocious puberty). Although those studies were performed in Bos taurus breeds (Angus and Hereford), similar findings were observed in our studies using Bos indicus-influenced heifers, which are later maturing. In these studies, heifers $(1 / 2$ Angus $\times 1 / 4$ Hereford $\times 1 / 4$ Brahman) were weaned between 3.5 and 4 months of age and fed a high-concentrate diet to promote a rate of body weight gain of approximately 1 $\mathrm{kg}$ /day (Cardoso et al., 2014a, b). This dietary regimen was shown to significantly advance puberty, with a high percentage $(\sim 85 \%)$ of heifers reaching puberty before 12 months of age.

To identify the developmental window in which heifers are most responsive to the nutritional programming of puberty, we employed a stair-step nutritional regimen involving alternate periods of dietary energy-restriction and re-feeding during juvenile development. Interestingly, we observed that heifers that gained body weight at high rates between 4 and 6.5 months of age, and were subsequently subjected to a marked restriction in feed intake between 6.5 and 9 months of age, still attained early puberty $(<12$ months of age) at rates comparable to heifers fed a highconcentrate diet continuously (Cardoso et al., 2014b). Similarly, Bos taurus heifers that were fed to gain body weight at a relatively high rate between 126 and 196 days of age exhibited a high incidence of precocious puberty (Gasser et al., 2006a). However, puberty was not advanced to the same extent when heifers were fed a similar diet later during juvenile development. Collectively, these results demonstrate that during early development, plausibly between 4 and 9 months of age, heifers are more sensitive to the pubertal acceleration effects of nutrition (Fig. 1).

\section{Nutritional Programming of Puberty in Heifers: Working Model}

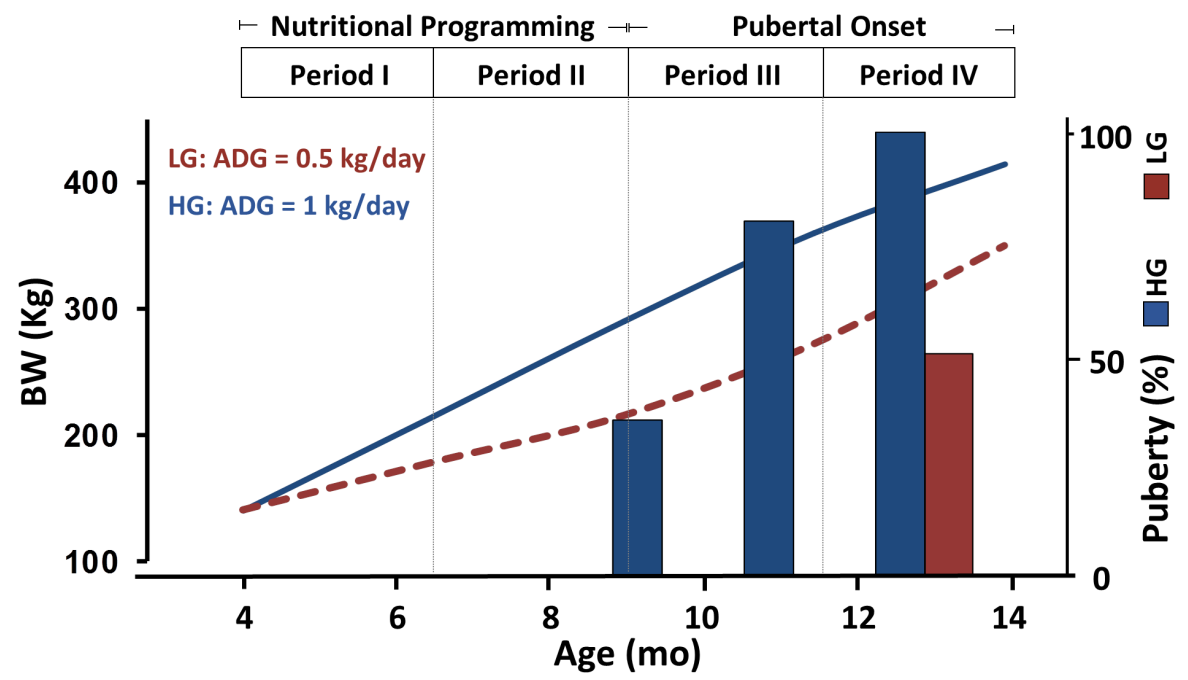

Figure 1. Schematic diagram of the working model for the nutritional programming of puberty in heifers. Heifers weaned at approximately 3.5 months of age and fed a high-concentrate diet to promote a relative high rate of body weight gain (1 kg/day; blue line) attain puberty significantly earlier (blue bars) when compared to heifers gaining body weight at lower rates $(0.5 \mathrm{~kg}$ /day; red line and bar). ADG: Average daily gain; BW: body weight; LG: lowgain; HG: high-gain. 


\section{Metabolic signals and neuroendocrine maturation}

Nutritional regimens that promote a relative high rate of body weight gain ( $1 \mathrm{~kg}$ /day) are accompanied by greater adiposity and increased circulating concentrations of the metabolic hormones leptin, insulin, and insulin-like growth factor 1 (IGF1) when compared to regimens that promote growth at a slower rate $(0.5 \mathrm{~kg} /$ day; Allen et al., 2012; Cardoso et al., 2014b; Alves et al., 2015). We hypothesized that this positive metabolic profile induced by increased body weight gain would promote modifications in the reproductive neuroendocrine system, ultimately resulting in increased pulsatile release of GnRH and $\mathrm{LH}$, which are required for first ovulation. Using the same research model of accelerated growth during the juvenile period, we characterized the secretion of $\mathrm{GnRH}$ and LH in prepubertal heifers by measuring the concentrations of $\mathrm{GnRH}$ in third-ventricle cerebrospinal fluid (IIIV-CSF) and LH in the peripheral blood, respectively (Cardoso et al., 2014a). As expected, we observed that all pulses of LH in blood plasma were preceded by a GnRH pulse in the IIIV-CSF and, more importantly, pulse frequency of GnRH and $\mathrm{LH}$ were greater in heifers gaining $1 \mathrm{~kg} /$ day when compared to heifers gaining $0.5 \mathrm{~kg}$ /day between 4 and 8 months of age. These observations further indicate that increased nutrition during the juvenile period advances puberty by promoting the maturation of the reproductive neuroendocrine axis, thus hastening the pubertal increase in the pulsatile release of $\mathrm{GnRH} / \mathrm{LH}$.

\section{Postnatal programming of hypothalamic signalling pathways}

A growing body of evidence indicates that metabolic factors associated with the individual's nutritional status can influence the activity of $\mathrm{GnRH}$ neurons. Among metabolic factors, leptin plays a critical role in conveying nutritional information to the neuroendocrine axis and controlling pubertal progression in heifers (Zieba et al., 2005). However, the long form of the leptin receptor $(\mathrm{ObRb})$, the main receptor isoform involved in activation of intracellular signaling, is not present on GnRH neurons (Quennell et al., 2009). Therefore, it has been postulated that leptin signaling influences $\mathrm{GnRH}$ neuronal activity via an upstream neuronal network that ultimately targets GnRH neurons (Barb and Kraeling, 2004; Ratra and Elias, 2014). Two different neuronal populations located in the ARC that contain ObRb (Cheung et al., 1997; Elmquist et al., 1998) and directly regulate the function of GnRH neurons (Roa and Herbison, 2012) have been established as main components of this network: the neuropeptide Y/agouti-related peptide (NPY/AgRP) and the proopiomelanocortin/cocaine- and amphetamineregulated transcript (POMC/CART) neurons. In addition, because the ARC population of kisspeptin neurons is involved in the control of GnRH pulsatile release (Li et al., 2009) and kisspeptin synthesis is responsive to metabolic cues (Castellano et al., 2011), kisspeptin neurons in the ARC are also likely to be involved in the nutritional regulation of puberty.

\section{Neuropeptide Y/AgRP pathway}

The NPY/AgRP neuronal population secretes two main orexigenic neuropeptides: neuropeptide $\mathrm{Y}$ (NPY) and agouti-related peptide (AgRP), both secreted predominantly in conditions of low energy balance (McShane et al., 1992; Hahn et al., 1998). Experiments in mature cows have demonstrated that NPY has an inhibitory effect on GnRH release (Gazal et al., 1998) and, although not tested in cattle, AgRP has been shown to suppress GnRH release in sheep (Miller et al., 2007) and monkeys (Vulliémoz et al., 2005). Both neuropeptides, NPY and AgRP, are important inhibitory signals to GnRH secretion during prepubertal development and play a key role in controlling the timing of pubertal maturation in females (Pierroz et al., 1995; Egan et al., 2017). Our studies in prepubertal heifers have shown that increased body weight gain between 4 and 8 months of age (juvenile period) reduces $A g R P$ (Allen et al., 2012) and NPY (Allen et al., 2012; Alves et al., 2015) mRNA expression in the ARC, decreases the concentrations of NPY in the cerebrospinal fluid collected from the third ventricle of the brain (Cardoso et al., 2014a), and reduces the magnitude of NPY neuronal inputs to GnRH neurons (Alves et al., 2015). Altogether, our findings in the bovine female support the notion that NPY and AgRP inhibit GnRH pulsatile release during the prepubertal period and nutritional regimens that promote accelerated rates of body weight gain during juvenile development can attenuate the NPY/AgRP inhibitory tone, thus facilitating pubertal maturation (Fig. 2).

\section{Proopiomelanocortin pathway}

The POMC gene expressed in POMC/CART neurons encodes several peptides, including the anorexigenic alpha-melanocyte stimulating hormone $(\alpha-$ MSH), which is produced primarily during periods of positive energy balance (Cone, 1999). In rodents, $\alpha$ MSH was shown to elicit a direct stimulatory effect on GnRH neurons (Leranth et al., 1988; Roa and Herbison, 2012) and administration of a melanocortin agonist stimulated LH secretion in the female sheep (Backholer et al., 2009). Notably, the melanocortin 4 receptor (MC4R) is antagonized by AgRP (Ollmann et al., 1997), indicating that AgRP may inhibit GnRH secretion not only directly but also indirectly via the melanocortin system. In our studies, the expression of $P O M C$ mRNA and $\alpha-\mathrm{MSH}$ immunostaining in the ARC were both increased in heifers that gained body weight at accelerated rates during juvenile development (Allen et al., 2012; Cardoso et al., 2015). However, the number of $\alpha$-MSH-immunopositive contacts on GnRH neurons was moderately low and was not affected by the nutritional status during early development (Cardoso et al., 2015). Collectively, these results suggest that the nutritional acceleration of puberty in heifers may require increased signaling of $\alpha-\mathrm{MSH}$ in the hypothalamus, but not necessarily involving an increase 
Cardoso et al. Neuroendocrine control of puberty in heifers.

in direct $\alpha$-MSH stimulation of GnRH neurons.

\section{Kisspeptin pathway}

There is emerging evidence indicating that the ARC population of kisspeptin neurons is involved in the nutritional control of reproductive function in females (Castellano et al., 2011). While a subset of kisspeptin neurons in the ARC contain ObRb (Backholer et al., 2010), leptin induction of STAT3 phosphorylation, a major intracellular signaling mechanism induced by leptin, is absent in kisspeptin neurons in sheep (Louis et al., 2011). Thus, the effects of leptin on kisspeptin expression and neuronal activity appear to be mediated indirectly via an upstream network of neurons (Donato et al., 2011; Manfredi-Lozano et al., 2016). In our studies in heifers, we tested if the number of close contacts of NPY- or $\alpha$-MSH-containing fibers on kisspeptin neurons in the ARC would be associated with the nutritional regulation of puberty in heifers. While the intensity of NPY axonal contacts on kisspeptin neurons was not affected by nutritional status (Alves et al., 2015), accelerated rates of body weight gain resulted in an increased number of $\alpha-\mathrm{MSH}$ immunopositive contacts on kisspeptin neurons and a greater percentage of kisspeptin neurons innervated by $\alpha$-MSH fibers (Cardoso et al., 2015). Prepubertal heifers subjected to accelerated rates of body weight gain also exhibited reduced Kiss 1 mRNA content in the ARC (Alves et al., 2015; Cardoso et al., 2015), suggesting a possible influence of $\alpha$-MSH on Kiss 1 gene expression during the juvenile period. Notably, a MTII melanocortin agonist has been shown to reduce Kiss 1 mRNA in the ARC of sheep (Backholer et al., 2009). In intact female rats, the developmental pattern of Kiss 1 expression in the ARC follows a U-like pattern, with expression declining from intermediate (infantile period), to minimal (juvenile period), followed by a postpubertal increase to maximum expression during adulthood (Cao and Patisaul, 2011). Therefore, reduced Kiss 1 expression in the ARC may indicate a more advanced stage of development of this neuronal population in heifers fed a higher plane of nutrition. Additionally, changes in Kiss 1 mRNA abundance in the ARC may result from the negative effects of estradiol on Kiss 1 expression (Smith, 2009), since steroidogenic capacity and circulating levels of estradiol increase as heifers approach puberty (Gasser et al., 2006b). Despite the observed changes in Kiss 1 mRNA expression, the number of kisspeptin-immunopositive neurons in the ARC was not affected by nutritional status in our studies (Alves et al., 2015; Cardoso et al., 2015). Based on those findings, the role of ARC kisspeptin neurons in the nutritional programming of puberty in heifers is still not fully understood. However, interactions between POMC and kisspeptin neurons appear to be relevant during this process (Fig. 2).
Other pathways

In addition to changes in neuronal populations and neuropeptide signaling as discussed above, the ARC encompasses other cell types and molecules impacting a variety of cellular processes that regulate $\mathrm{GnRH}$ secretion, including receptors and transcription factors. In two of our studies in prepubertal heifers, we obtained a comprehensive survey of the different cellular populations of the ARC by isolating ARC tissue from within hypothalamic sections. In one experiment (Allen et al., 2012), using microarray analyses to assess mRNA abundance, we observed that different nutritional regimens applied during the juvenile period promoted differential expression of a large number of genes, including those encoding for prolactin-releasing hormone receptor $(P R L H R)$ and growth hormone receptor $(G H R)$. In addition, we observed differential expression of genes associated with control of feed intake and metabolism ( $N P Y, A g R P$, and $P O M C$ ), as well as genes involved in synaptic vesicle transport, axonal growth and neuronal plasticity. These findings, in conjunction with observed changes in neuronal projections (Alves et al., 2015; Cardoso et al., 2015), support the premise that neuronal remodeling plays a significant role in programming the timing of puberty in heifers. The well-established neurotropic actions of leptin are likely to be involved in this process (Bouret et al., 2004).

In a follow-up study (Alves et al., 2016), we investigated if DNA methylation (key epigenetic mechanism for regulation of gene expression) in the ARC was influenced by nutritional status during the juvenile period. Differential methylation was found in several genes, including GHR and HMGA2 (a gene that encodes a chromatin-associated protein that modulates transcription), which were hypermethylated in heifers that gained body weight at higher rates. Importantly, the hypermethylation of these genes was associated with a reduced abundance of their mRNA expression levels. Growth hormone has been previously reported to play a role in pubertal development in heifers (Simpson et al., 1991) and its action in the ARC appears to be linked to the control of NPY synthesis (Chan et al., 1996). Moreover, a genome-wide association study (GWAS) has indicated that $H M G A 2$ is one prominent gene involved in the process of pubertal maturation in heifers (Fortes et al., 2011), therefore, further investigation of its role in the nutritional programming of puberty is warranted. While the exact mechanisms remain unknown, this initial investigation of DNA methylation supports the premise that epigenetic alterations promoted by increased body weight gain during the juvenile period may represent a suitable mechanism by which nutrition can change functionality of the ARC cellular machinery, thus facilitating the activation of the reproductive neuroendocrine axis. 


\section{Model for the Metabolic Activation of GnRH Neurosecretion in Heifers}

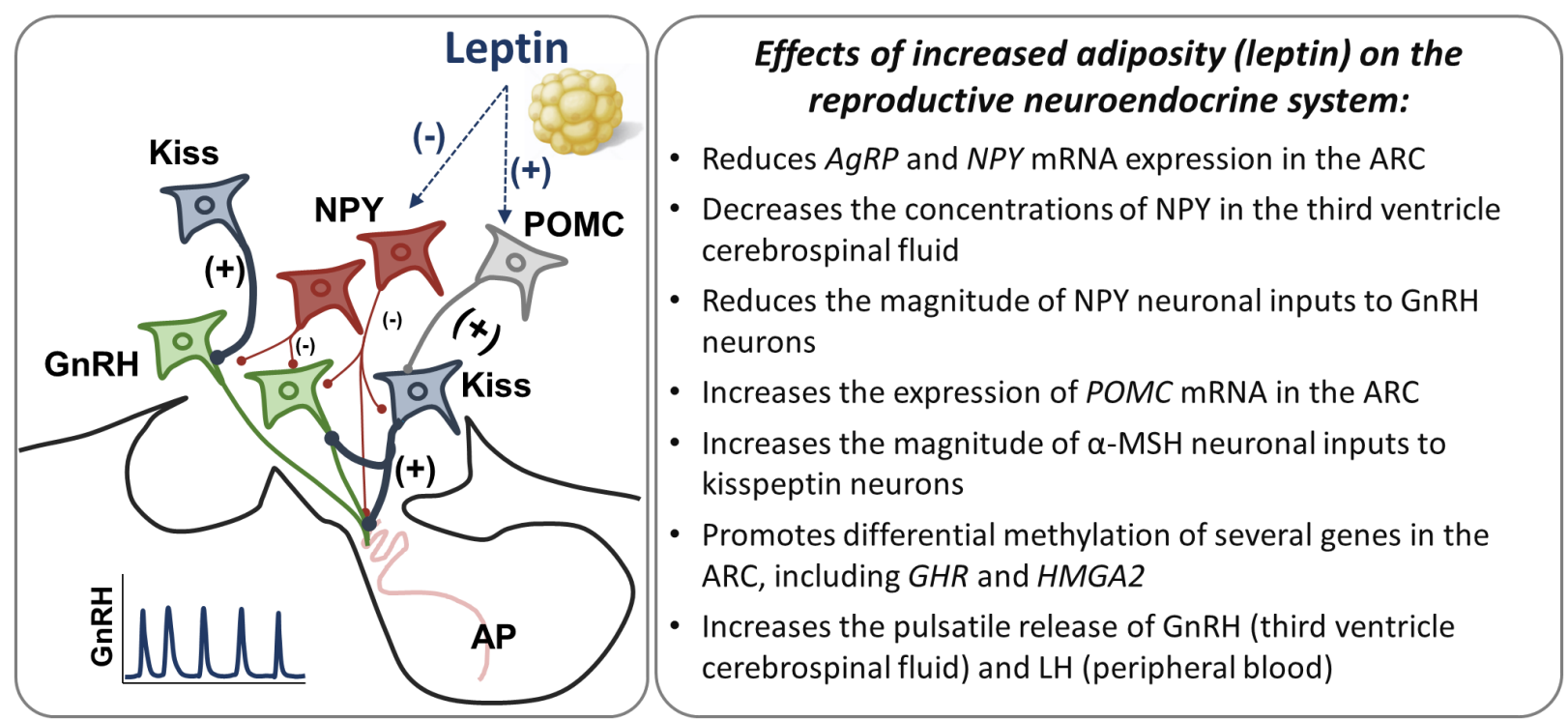

Figure 2. Neuroendocrine model for the metabolic activation of GnRH secretion during pubertal maturation in heifers. Left Panel: Representative scheme of neuronal pathways in the arcuate nucleus (ARC) that mediate the effects of leptin on GnRH pulsatile secretion. The adipocyte-derived hormone leptin inhibits (-) neuropeptide Y (NPY) and stimulates (+) proopiomelanocortin (POMC) neurons in the ARC. Consequently, the inhibitory (-) effects of NPY on GnRH neurons are diminished (thickness of lines relates to the intensity of the stimulus). POMC neurons project to kisspeptin (Kiss) neurons in the ARC, which stimulate $(+)$ the pulsatile release of GnRH. The suppression of inhibitory (NPY) and increase in stimulatory (POMC and Kiss) pathways promote an increase in the frequency of GnRH pulses. GnRH neurons project to the hypophyseal portal circulation, allowing the access of this neurohormone to the anterior pituitary (AP), where it stimulates the secretion of gonadotropins. Right Panel: Summary of the effects of increased rates of body weight gain during the juvenile period on the reproductive neuroendocrine system in heifers.

\section{Prenatal programming of hypothalamic signalling pathways}

During the past decade, the developmental origins of health and disease (DOHaD) hypothesis by Barker and colleagues has attracted considerable attention to the concept of fetal programming (Barker, 2007). The $\mathrm{DOHaD}$ hypothesis gained momentum particularly after the emergence of epidemiological data from the 19441945 Dutch famine cohort demonstrating that maternal malnutrition during gestation is associated with a marked increase in the risks of the offspring for developing cardiovascular and metabolic diseases (Ravelli et al., 1976). These findings, in conjunction with subsequent clinical and animal studies (Barker, 2004; Gluckman and Hanson, 2004; Nijland et al., 2008), demonstrate that the perinatal period, a period in which organogenesis and tissue differentiation occur through a tightly controlled and timed process, is a critical window of opportunity for programming the offspring's phenotype.

In recent years, it has become evident that the mechanisms underlying the developmental origins of the adult phenotype require reprogramming of the epigenome by environmental factors (Ganu et al., 2012; Trevino et al., 2015). This is possible during fetal life due to the plasticity that allows the developing organism to adopt a phenotype that best suits the environment. From a neuroendocrine standpoint, studies in laboratory rodents have shown that maternal nutrition during gestation modulates the hypothalamic neurocircuitries controlling $\mathrm{GnRH}$ pulsatile release, thus programing pubertal maturation in the female offspring (Léonhardt et al., 2003; Iwasa et al., 2010; Sanchez-Garrido et al., 2013). In cattle, however, the concept of prenatal programing of the reproductive neuroendocrine axis remains virtually unexplored. For the past several years, our research group has developed a bovine model to study the interactive effects of prenatal and early postnatal nutrition on reproductive function in the female offspring. To accomplish this, Bos indicusinfluenced (Brahman $\times$ Hereford; Brangus) cows bearing female pregnancies were fed to achieve thin, moderate, or obese body condition (BC) by approximately 6 months of gestation (second trimester) and maintained at the target $\mathrm{BC}$ until calving. Heifer offspring from each maternal group were then weaned at approximately 3.5 months of age and assigned randomly to be fed to achieve a relatively low ( 0.5 $\mathrm{kg}$ /day) or high $(1 \mathrm{~kg}$ /day) rate of body weight gain until 8 months of age. While results of most of our studies using this animal model remain pending, initial findings are summarized in the following sections. 


\section{Leptin transport across the blood-brain barrier}

As discussed previously, leptin is a critical metabolic hormone conveying nutritional information to the neuroendocrine axis and controlling pubertal development in females. Previous studies in sheep have shown that changes in nutritional status can modulate the transport of leptin across the blood-brain barrier. For example, in a study in which obese and lean adult sheep were fed to either gain or lose body weight, it was observed that obese animals had impaired transport of leptin across the blood-brain barrier (Adam and Findlay, 2010). Moreover, the transport of peripherallyadministered leptin across the blood-brain barrier in obese sheep was not reversed following significant body weight loss. These and other data suggest that exposure of animals to a hyperleptinemic environment, such as that expected to occur in the fetus of a dam on a high nutritional plane, can result in irreversible physiological changes within the blood-brain barrier. Thus, we hypothesized that heifer offspring of dams with broadly varying degrees of $\mathrm{BC}$ may develop a leptin resistant state due to structural alterations in the blood-brain barrier.

To test this hypothesis, we investigated the expression of different isoforms of the leptin receptor in the choroid plexus of heifers subjected to the different maternal (thin, moderate, and obese) and postnatal (low and high) nutritional treatments. Importantly, the transport of leptin across the blood-brain barrier has been shown to depend on expression of the short form of the leptin receptor, which acts as a leptin transporter in endothelial cells (Banks, 2001). We found that prenatal nutrient restriction significantly reduced the mRNA abundance of the short form of the leptin receptor ObRc in the choroid plexus of heifers at 8 months of age (Zhang et al., 2017). Moreover, the expression of total leptin receptor (ObRt) was also reduced in the choroid plexus of heifers subjected to prenatal undernutrition. Interestingly, postnatal nutrient restriction increased the expression of $\mathrm{ObRb}$, the long form of the leptin receptor, in the choroid plexus of heifers subjected to prenatal undernutrition but not in heifers subjected to other prenatal nutritional treatments (moderate or obese) Collectively, these results indicate that undernutrition during pregnancy interacts with postnatal nutrition to modulate the expression of the different isoforms of the leptin receptor in the choroid plexus of prepubertal heifers. The significance of changes in leptin receptor expression in regard to leptin transport across the bloodbrain barrier is currently being investigated.

\section{Neuropeptide y pathway}

Using hypothalamic tissue from the same group of heifers discussed above, we investigated the interactive effects of prenatal and postnatal nutrition on the extent of NPY (inhibitory) projections toward GnRH neurons. While none of the treatment combinations altered the number of GnRH neurons, reduced rates of body weight gain during postnatal development increased the proportion of GnRH neurons in close apposition to NPY-containing fibers (Zhang et al., 2017). Notably, these effects were significantly greater in heifers from nutritionally-restricted dams, suggesting that prenatal undernutrition may amplify the effects of postnatal nutrition modulating the extent of NPY neuronal projections to GnRH neurons. While the functional relevance of this phenomenon remains to be determined, it is likely that the effects of prenatal undernutrition on NPY projections to GnRH neurons will hinder the process of pubertal maturation in heifers.

\section{Ongoing and future studies}

In our ongoing and future studies, we will further examine the interactive effects of prenatal nutrition with nutritional treatments imposed postnatally during the early juvenile period on hypothalamic processes controlling puberty. These include changes in expression of key genes (e.g., Kiss 1, POMC, and NPY) in specific hypothalamic nuclei, epigenetic modification (e.g., DNA methylation patterns), morphological development of neuronal pathways that modulate activity of the GnRH pulse generator, leptin signaling in the hypothalamus, among others. Importantly, we currently have available a large group of nutritionallyprogrammed heifers that will allow us to characterize the interactive effects of prenatal and early postnatal nutrition on multiple physiological processes, such as leptin transport across the blood-brain barrier, central release of neuropeptides, pulsatile secretion of GnRH and $\mathrm{LH}$, responsiveness to estradiol negative and positive feedback, and estrous cycle events associated with postpubertal maturation. Moreover, because organizational changes brought about through perinatal nutritional programming are believed to be imprinted in the genome, they are likely to be associated with consistent physiological events that may, in some cases, be manifested only later in life. Thus, these nutritionally-programmed females represent a valuable resource for evaluating the long-term consequences of perinatal nutrition on reproductive function of sexually mature animals. We believe that the perinatal nutritional environment can program how the reproductive neuroendocrine axis of sexually mature heifers responds to leptin and other metabolic/hormonal factors, particularly under unfavorable metabolic conditions.

Finally, it will be important in the future to determine the transgenerational effects of perinatal nutrition in the bovine female. Studies in rodents have shown that experimental manipulation of the nutritional plane during the perinatal period can significantly impact the reproductive and metabolic phenotypes of subsequent generations (Pinheiro et al., 2008; Pentinat et al., 2010; Burdge et al., 2011). While these studies are difficult to perform in cattle due to the long generation interval, a better understanding of this process can have important implications for lifetime animal health and productivity.

\section{Acknowledgments}

This work was supported by the USDA 
National Institute of Food and Agriculture, Hatch project 1012280 (RCC) and AFRI project 2013-6701520960 (GLW).

\section{References}

Adam C, Findlay P. 2010. Decreased blood-brain leptin transfer in an ovine model of obesity and weight loss: resolving the cause of leptin resistance. Int J Obes, 34:980-988.

Allen C, Alves BRC, Li X, Tedeschi LO, Zhou H, Paschal JC, Riggs PK, Braga-Neto UM, Keisler DH, WilliamsGL, Amstalden M. 2012. Gene expression in the arcuate nucleus of heifers is affected by controlled intake of high-and low-concentrate diets. J Anim Sci, 90:2222-2232.

Allen C, Tedeschi LO, Keisler DH, Cardoso RC, Alves BRC, Amstalden M, Williams GL. 2017. Interaction of dietary energy source and body weight gain during the juvenile period on metabolic endocrine status and age at puberty in beef heifers. J Anim Sci, 95:2080-2088.

Alves BR, Cardoso RC, Prezotto LD, Thorson JF, Bedenbaugh M, Sharpton SM, Caraty A, Keisler DH, Tedeschi LO, Williams GL, Amstalden M. 2015. Elevated body weight gain during the juvenile period alters neuropeptide Y-gonadotropin-releasing hormone circuitry in prepubertal heifers. Biol Reprod, 92:46:1-10.

Alves BR, Cardoso RC, Doan R, Zhang Y, Dindot SV, Williams GL, Amstalden M. 2016. Nutritional programming of accelerated puberty in heifers: alterations in DNA methylation in the arcuate nucleus. Biol Reprod, 96:174-184.

Amstalden M, Alves BR, Liu S, Cardoso RC, Williams GL. 2011. Neuroendocrine pathways mediating nutritional acceleration of puberty: insights from ruminant models. Front Endocrinol, 2:3389. doi: 10.3389/fendo.2011.00109.

Backholer K, Smith J, Clarke IJ. 2009. Melanocortins may stimulate reproduction by activating orexin neurons in the dorsomedial hypothalamus and kisspeptin neurons in the preoptic area of the ewe. Endocrinology, 150:5488-5497.

Backholer K, Smith JT, Rao A, Pereira A, Iqbal J, Ogawa S, Li Q, Clarke IJ. 2010. Kisspeptin cells in the ewe brain respond to leptin and communicate with neuropeptide $\mathrm{Y}$ and proopiomelanocortin cells Endocrinology, 151:2233-2243.

Banks WA. 2001. Leptin transport across the bloodbrain barrier: implications for the cause and treatment of obesity. Curr Pharm Des, 7:125-133.

Barb C, Kraeling R. 2004. Role of leptin in the regulation of gonadotropin secretion in farm animals. Anim Reprod Sci, 82:155-167.

Barker DJ. 2004. The developmental origins of adult disease. J Am Coll Nutr, 23:588S-595S.

Barker DJ. 2007. The origins of the developmental origins theory. J Intern Med, 261:412-417.

Bedenbaugh MN, D'Oliveira M, Cardoso RC, Hileman SM, Williams GL, Amstalden M. 2018. Pubertal escape from estradiol negative feedback in ewe lambs is not accounted for by decreased ESR1 mRNA or protein in kisspeptin neurons. Endocrinology, 159:426-438.

Bouret SG, Draper SJ, Simerly RB. 2004. Trophic action of leptin on hypothalamic neurons that regulate feeding. Science, 304:108-110.

Bronson F. 1981. The regulation of luteinizing hormone secretion by estrogen: relationships among negative feedback, surge potential, and male stimulation in juvenile, peripubertal, and adult female mice. Endocrinology, 108:506-516.

Burdge GC, Hoile SP, Uller T, Thomas NA, Gluckman PD, Hanson MA, Lillycrop KA. 2011. Progressive, transgenerational changes in offspring phenotype and epigenotype following nutritional transition. PloS One, 6:e28282. doi.org/10.1371/ journal.pone.0028282.

Cao J, Patisaul HB. 2011. Sexually dimorphic expression of hypothalamic estrogen receptors $\alpha$ and $\beta$ and Kiss 1 in neonatal male and female rats. $J$ Comp Neurol, 519:2954-2977.

Cardoso RC, Alves BR, Prezotto LD, Thorson JF, Tedeschi LO, Keisler DH, Amstalden M, Williams GL. 2014a. Reciprocal changes in leptin and NPY during nutritional acceleration of puberty in heifers. $J$ Endocrinol, 223:289-298.

Cardoso RC, Alves BR, Prezotto LD, Thorson JF, Tedeschi LO, Keisler DH, Park CS, Amstalden M, Williams GL. 2014b. Use of a stair-step compensatory gain nutritional regimen to program the onset of puberty in beef heifers. J Anim Sci, 92:2942-2949.

Cardoso RC, Alves BR, Sharpton SM, Williams GL, Amstalden M. 2015. Nutritional programming of accelerated puberty in heifers: involvement of pro-opiomelanocortin neurones in the arcuate nucleus. $J$ Neuroendocrinol, 27:647-657.

Castellano JM, Bentsen AH, Sánchez-Garrido MA, Ruiz-Pino F, Romero M, Garcia-Galiano D, Aguilar E, Pinilla L, Diéguez C, Mikkelsen JD, TenaSempere M. 2011. Early metabolic programming of puberty onset: impact of changes in postnatal feeding and rearing conditions on the timing of puberty and development of the hypothalamic kisspeptin system. Endocrinology, 152:3396-3408.

Chan YY, Clifton DK, Steiner RA. 1996. Role of NPY neurones in GH-dependent feedback signalling to the brain. Horm Res, 45:12-14.

Cheong RY, Czieselsky K, Porteous R, Herbison AE. 2015. Expression of ESR1 in glutamatergic and GABAergic neurons is essential for normal puberty onset, estrogen feedback, and fertility in female mice. $J$ Neurosci, 35:14533-14543.

Cheung CC, Clifton DK, Steiner RA. 1997. Proopiomelanocortin neurons are direct targets for leptin in the hypothalamus. Endocrinology, 138:44894492.

Cone RD. 1999. The central melanocortin system and energy homeostasis. Trends Endocrinol Metab, 10:211216.

Day M, Imakawa K, Garcia-Winder M, Zalesky DD, Schanbacher BD, Kittok RJ, Kinder JE. 1984. Endocrine mechanisms of puberty in heifers: estradiol negative feedback regulation of luteinizing hormone 
secretion. Biol Reprod, 31:332-341.

Day M, Imakawa K, Garcia-Winder M, Kittok RJ, Schanbacher BD, Kinder JE. 1986. Influence of prepubertal ovariectomy and estradiol replacement therapy on secretion of luteinizing hormone before and after pubertal age in heifers. Domest Anim Endocrinol, 3:17-25.

Day M, Imakawa K, Wolfe P, Kittok R, Kinder J. 1987. Endocrine mechanisms of puberty in heifers. Role of hypothalamo-pituitary estradiol receptors in the negative feedback of estradiol on luteinizing hormone secretion. Biol Reprod, 37:1054-1065.

Donato J Jr, Cravo RM, Frazão R, Gautron L, Scott MM, Lachey J, Castro IA, Margatho LO, Lee S, Lee C, Richardson JA, Friedman J, Chua S Jr, Coppari R, Zigman JM, Elmquist JK, Elias CF. 2011. Leptin's effect on puberty in mice is relayed by the ventral premammillary nucleus and does not require signaling in Kiss1 neurons. J Clin Invest, 121:355-368.

Dorling AA, Todman MG, Korach KS, Herbison AE. 2003. Critical role for estrogen receptor alpha in negative feedback regulation of gonadotropin-releasing hormone mRNA expression in the female mouse. Neuroendocrinology, 78:204-209.

Dubois SL, Wolfe A, Radovick S, Boehm U, Levine JE. 2016. Estradiol restrains prepubertal gonadotropin secretion in female mice via activation of ER $\alpha$ in kisspeptin neurons. Endocrinology, 157:1546-1554.

Egan OK, Inglis MA, Anderson GM. 2017. Leptin signaling in AgRP neurons modulates puberty onset and adult fertility in mice. J Neurosci, 37:3875-3886.

Elmquist JK, Bjørbaek C, Ahima RS, Flier JS, Saper CB. 1998. Distributions of leptin receptor mRNA isoforms in the rat brain. J Comp Neurol, 395:535-547.

Fortes MR, Reverter A, Nagaraj SH, Zhang Y, Jonsson NN, Barris W, Lehnert S, Boe-Hansen GB, Hawken RJ. 2011. A single nucleotide polymorphismderived regulatory gene network underlying puberty in 2 tropical breeds of beef cattle. J Anim Sci, 89:1669-1683.

Foster DL, Lemons JA, Jaffe RB, Niswender GD. 1975. Sequential patterns of circulating luteinizing hormone and follicle-stimulating hormone in female sheep from early postnatal life through the first estrous cycles. Endocrinology, 97:985-994.

Foster DL, Ryan KD. 1979. Endocrine mechanisms governing transition into adulthood: a marked decrease in inhibitory feedback action of estradiol on tonic secretion of luteinizing hormone in the lamb during puberty. Endocrinology, 105: 896-904.

Funabashi T, Daikoku S, Shinohara K, Kimura F. 2000. Pulsatile gonadotropin-releasing hormone $(\mathrm{GnRH})$ secretion is an inherent function of $\mathrm{GnRH}$ neurons, as revealed by the culture of medial olfactory placode obtained from embryonic rats Neuroendocrinology, 71:138-144.

Ganu RS, Harris RA, Collins K, Aagaard KM. 2012. Maternal diet: a modulator for epigenomic regulation during development in nonhuman primates and humans. Int J Obes Suppl, 2:S14-S18.

Gasser CL, Behlke EJ, Grum DE, Day ML. 2006a. Effect of timing of feeding a high-concentrate diet on growth and attainment of puberty in early-weaned heifers. J Anim Sci, 84:3118-3122.

Gasser CL, Bridges GA, Mussard ML, Grum DE, Kinder JE, Day ML. 2006b. Induction of precocious puberty in heifers III: Hastened reduction of estradiol negative feedback on secretion of luteinizing hormone. J Anim Sci, 84:2050-2056.

Gazal OS, Leshin LS, Stanko RL, Thomas MG, Keisler DH, Anderson LL, Williams GL. 1998. Gonadotropin-releasing hormone secretion into thirdventricle cerebrospinal fluid of cattle: correspondence with the tonic and surge release of luteinizing hormone and its tonic inhibition by suckling and neuropeptide Y. Biol Reprod, 59:676-683.

Gluckman PD, Hanson MA. 2004. Developmental origins of disease paradigm: a mechanistic and evolutionary perspective. Pediatr Res, 56:311-317.

Goodman RL, Hileman SM, Nestor CC, Porter KL, Connors JM, Hardy SL, Millar RP, Cernea M, Coolen LM, Lehman MN. 2013. Kisspeptin, neurokinin $\mathrm{B}$, and dynorphin act in the arcuate nucleus to control activity of the GnRH pulse generator in ewes. Endocrinology, 154:4259-4269.

Hahn TM, Breininger JF, Baskin DG, Schwartz MW. 1998. Coexpression of Agrp and NPY in fastingactivated hypothalamic neurons. Nat Neurosci, 1:271272.

Hughes H. 2013. Raised replacement heifers: Some economic considerations. Vet Clin North Am Food Anim Pract, 29:643-652.

Iwasa T, Matsuzaki T, Murakami M, Fujisawa S, Kinouchi R, Gereltsetseg G, Kuwahara A, Yasui T, Irahara M. 2010. Effects of intrauterine undernutrition on hypothalamic Kiss1 expression and the timing of puberty in female rats. J Physiol, 588:821-829.

Kato J, Atsumi Y, Inaba M. 1974. Estradiol receptors in female rat hypothalamus in the developmental stages and during pubescence. Endocrinology, 94:309-317.

Kinder JE, Day M, Kittok R. 1987. Endocrine regulation of puberty in cows and ewes. $J$ Reprod Fertil Suppl, 34:167-186.

Lehman MN, Ebling FJ, Moenter SM, Karsch FJ. 1993. Distribution of estrogen receptor-immunoreactive cells in the sheep brain. Endocrinology, 133:876-886.

Lehman MN, Coolen LM, Goodman RL. 2010. Minireview: kisspeptin/neurokinin B/dynorphin (KNDy) cells of the arcuate nucleus: a central node in the control of gonadotropin-releasing hormone secretion. Endocrinology, 151:3479-3489.

Léonhardt M, Lesage J, Croix D, Dutriez-Casteloot I, Beauvillain JC, Dupouy JP. 2003. Effects of perinatal maternal food restriction on pituitary-gonadal axis and plasma leptin level in rat pup at birth and weaning and on timing of puberty. Biol Reprod, 68:390400.

Leranth C, MacLusky NJ, Shanabrough M, Naftolin F. 1988. Immunohistochemical evidence for synaptic connections between pro-opiomelanocortinimmunoreactive axons and LH-RH neurons in the preoptic area of the rat. Brain Res, 449:167-176.

Lesmeister J, Burfening P, Blackwell R. 1973. Date of first calving in beef cows and subsequent calf production. J Anim Sci, 36:1-6. 
Li XF, Kinsey-Jones JS, Cheng Y, Knox AM, Lin Y, Petrou NA, Roseweir A, Lightman SL, Milligan SR, Millar RP, O'Byrne KT. 2009. Kisspeptin signalling in the hypothalamic arcuate nucleus regulates $\mathrm{GnRH}$ pulse generator frequency in the rat. PloS One, 4:e8334. doi: 10.1371/journal.pone.0008334.

Louis GW, Greenwald-Yarnell M, Phillips R, Coolen LM, Lehman MN, Myers MG Jr. 2011. Molecular mapping of the neural pathways linking leptin to the neuroendocrine reproductive axis. Endocrinology, 152:2302-2310.

Manfredi-Lozano M, Roa J, Ruiz-Pino F, Piet R, Garcia-Galiano D, Pineda R, Zamora A, Leon S, Sanchez-Garrido MA, Romero-Ruiz A, Dieguez C, Vazquez MJ, Herbison AE, Pinilla L, Tena-Sempere M. 2016. Defining a novel leptin-melanocortinkisspeptin pathway involved in the metabolic control of puberty. Mol Metab, 5:844-857.

Mayer C, Acosta-Martinez M, Dubois SL, Wolfe A, Radovick S, Boehm U, Levine JE. 2010. Timing and completion of puberty in female mice depend on estrogen receptor $\alpha$-signaling in kisspeptin neurons. Proc Natl Acad Sci USA, 107:22693-22698.

McShane TM, May T, Miner JL, Keisler DH. 1992. Central actions of neuropeptide-Y may provide a neuromodulatory link between nutrition and reproduction. Biol Reprod, 46:1151-1157.

Miller DW, Harrison JL, Bennett EJ, Findlay PA, Adam CL. 2007. Nutritional influences on reproductive neuroendocrine output: insulin, leptin, and orexigenic neuropeptide signaling in the ovine hypothalamus. Endocrinology, 148:5313-5322.

Navarro VM, Gottsch ML, Chavkin C, Okamura H, Clifton DK, Steiner RA. 2009. Regulation of gonadotropin-releasing hormone secretion by kisspeptin/dynorphin/neurokinin B neurons in the arcuate nucleus of the mouse. J Neurosci, 29:1185911866.

Nijland MJ, Ford SP, Nathanielsz PW. 2008. Prenatal origins of adult disease. Curr Opin Obstet Gynecol, 20:132-138.

Ollmann MM, Wilson BD, Yang YK, Kerns JA, Chen Y, Gantz I, Barsh GS. 1997. Antagonism of central melanocortin receptors in vitro and in vivo by agouti-related protein. Science, 278:135-138.

Pentinat T, Ramon-Krauel M, Cebria J, Diaz R, Jimenez-Chillaron JC. 2010. Transgenerational inheritance of glucose intolerance in a mouse model of neonatal overnutrition. Endocrinology, 151:5617-5623.

Pierroz DD, Gruaz NM, d'Alièves V, Aubert ML. 1995. Chronic administration of neuropeptide $Y$ into the lateral ventricle starting at 30 days of life delays sexual maturation in the female rat. Neuroendocrinology, 61:293-300

Pinheiro AR, Salvucci ID, Aguila MB, Mandarimde-Lacerda CA. 2008. Protein restriction during gestation and/or lactation causes adverse transgenerational effects on biometry and glucose metabolism in F1 and F2 progenies of rats. Clin Sci, 114:381-392.

Qiu J, Nestor CC, Zhang C, Padilla SL, Palmiter RD, Kelly MJ, Rønnekleiv OK. 2016. High-frequency stimulation-induced peptide release synchronizes arcuate kisspeptin neurons and excites GnRH neurons. Elife,5:e16246. doi: 10.7554/eLife.16246.

Quennell JH, Mulligan AC, Tups A, Liu X, Phipps SJ, Kemp CJ, Herbison AE, Grattan DR, Anderson GM. 2009. Leptin indirectly regulates gonadotropinreleasing hormone neuronal function. Endocrinology, 150:2805-2812.

Ratra DV, Elias CF. 2014. Chemical identity of hypothalamic neurons engaged by leptin in reproductive control. J Chem Neuroanat, 61:233-238.

Ravelli GP, Stein ZA, Susser MW. 1976. Obesity in young men after famine exposure in utero and early infancy. N Engl J Med, 295:349-353.

Redmond JS, Baez-Sandoval GM, Spell KM, Spencer TE, Lents CA, Williams GL, Amstalden M. 2011a. Developmental changes in hypothalamic Kiss1 expression during activation of the pulsatile release of luteinising hormone in maturing ewe lambs. $J$ Neuroendocrinol, 23:815-822.

Redmond JS, Macedo GG, Velez IC, Caraty A, Williams GL, Amstalden M. 2011b. Kisspeptin activates the hypothalamic-adenohypophyseal-gonadal axis in prepubertal ewe lambs. Reproduction, 141:541548.

Roa J, Herbison AE. 2012. Direct regulation of GnRH neuron excitability by arcuate nucleus POMC and NPY neuron neuropeptides in female mice. Endocrinology, 153:5587-5599.

Ryan KD, Foster DL. 1980. Neuroendocrine mechanisms involved in onset of puberty in the female: concepts derived from the lamb. Fed Proc, 39:23722377.

Sánchez-Garrido MA, Castellano JM, Ruiz-Pino F, Garcia-Galiano D, Manfredi-Lozano $M$, Leon S, Romero-Ruiz A, Diéguez C, Pinilla L, Tena-Sempere M. 2013. Metabolic programming of puberty: sexually dimorphic responses to early nutritional challenges. Endocrinology, 154:3387-3400.

Schams D, Schallenberger E, Gombe S, Karg H. 1981. Endocrine patterns associated with puberty in male and female cattle. J Reprod Fertil Suppl, 30:103110 .

Short R, Bellows R. 1971. Relationships among weight gains, age at puberty and reproductive performance in heifers. J Anim Sci, 32:127-131.

Simpson RB, Armstrong JD, Harvey RW, Miller DC, Heimer EP, Campbell RM. 1991. Effect of active immunization against growth hormone-releasing factor on growth and onset of puberty in beef heifers. $J$ Anim Sci, 69:4914-4924.

Sisk CL, Foster DL. 2004. The neural basis of puberty and adolescence. Nat Neurosci, 7:1040-1047.

Sizonenko PC, Aubert ML. 1986. Neuroendocrine changes characteristic of sexual maturation. J Neural Transm Suppl, 21:159-181.

Smith JT. 2009. Sex steroid control of hypothalamic Kiss1 expression in sheep and rodents: comparative aspects. Peptides, 30:94-102.

Staigmiller R, Short R, Bellows R. 1979. Induction of LH surges with $17 \beta$ estradiol in prepuberal beef heifers: an age dependent response. Theriogenology, 11:453- 
459.

Swanson L, Hafs H, Morrow D. 1972. Ovarian characteristics and serum LH, prolactin, progesterone and glucocorticoid from first estrus to breeding size in Holstein heifers. J Anim Sci, 34:284-293.

Terasawa E, Guerriero KA, Plant TM. 2013. Kisspeptin and puberty in mammals. Adv Exp Med Biol, 784:253-273.

Trevino LS, Wang Q, Walker CL. 2015. Phosphorylation of epigenetic "readers, writers and erasers": Implications for developmental reprogramming and the epigenetic basis for health and disease. Prog Biophys Mol Biol, 118:8-13.

Vulliémoz NR, Xiao E, Xia-Zhang L, Wardlaw SL, Ferin M. 2005. Central infusion of agouti-related peptide suppresses pulsatile luteinizing hormone release in the ovariectomized rhesus monkey. Endocrinology, 146:784-789.

Zhang Y, O’Neil MM, Scarpa JO, Alves BRC, Welsh Jr. TH, Cardoso RC, Williams GL. 2017. Perinatal nutrition alters NPY neuronal projections to GnRH neurons and leptin receptor expression in the choroid plexus of prepubertal heifer. In: Proceedings of the 50th Annual Meeting of the Society for the Study of Reproduction, 2017, Washington, DC.Washington, DC: SSR. pp. 283 (Abstract).

Zieba D, Amstalden M, Williams G. 2005. Regulatory roles of leptin in reproduction and metabolism: a comparative review. Domest Anim Endocrinol, 29:166185. 